\title{
Length-weight relationships and condition factors of Cephalopholis argus harvested in the northern coast of Aceh, Indonesia
}

\author{
Nur Fadli $^{1 *}$, Adrian Damora ${ }^{1}$, Zainal Abidin Muchlisin ${ }^{1}$, Irma Dewiyanti ${ }^{1}$, Mutia Ramadhaniaty $^{1}$, Rianjuanda \\ Djamani ${ }^{1}$, Alfis Syahril ${ }^{1}$, Firman M. Nur ${ }^{2}$, Agung S. Batubara ${ }^{3}$, Nanda Muhammad Razi ${ }^{1}$, Edison D. Macusi ${ }^{4}$ and \\ Mohd N. Siti-Azizah ${ }^{5}$ \\ ${ }^{1}$ Faculty of Marine and Fisheries, Universitas Syiah Kuala, Banda Aceh, Indonesia \\ ${ }^{2}$ Graduate School of Mathematics and Applied Sciences, Universitas Syiah Kuala, Banda Aceh 23111, Indonesia \\ ${ }^{3}$ Faculty of Mathematics and Natural Sciences, Universitas Negeri Medan, North Sumatra 20221, Indonesia \\ ${ }^{4}$ Institute of Agriculture and Life Sciences (IALS), Davao Oriental State University (DOrSU), Mati City, Davao Oriental, Philippines \\ ${ }^{5}$ Institute of Marine Biotechnology, Universiti Malaysia Terengganu, Terengganu, Malaysia
}

\begin{abstract}
The peacock hind grouper (Cephalopholis argus) is among several highly exploited grouper fishes globally. Categorized as least concern (LC) in the IUCN, biological data on the species is limited, especially in the Aceh region. This research targeted to investigate the biological features of the C. argus fished on the northern coast of Aceh. The fish samples were collected from Pelabuhan Perikanan Samudera (PPS) Lampulo, Kuta Alam District, Banda Aceh, Aceh from June - September 2020. Overall, 30 specimens C. argus were compiled in this study. The total length (TL) varied between $136.0-284.0 \mathrm{~mm}$, while weight (W) ranged between 46.5-460.0 g. In addition, Fulton's condition $(\mathrm{K})$ ranged from 1.45-4.61, and relative weight $(\mathrm{Wr})$ ranged from $81.75-128.53 \mathrm{~g}$. The LWRs analysis revealed a b value of 3.1329 with a correlation coefficient of 0.94 , indicating a positive allometric growth pattern. This study provides length-weight relationships (LWR) and condition factors value for the peacock hind grouper that will assist in building a feasible management of the fish.
\end{abstract}

\section{Introduction}

One of the groupers species fished in Aceh northern coast is the peacock hind grouper (Cephalopholis argus). The fish is categorized as least concern (LC) in the IUCN List [1]. Cephalopholis argus is distributed in the Indo-Pacific from the Red Sea to South Africa and eastward to French Polynesia and the Pitcairn group, Ryukyus Islands and Ogasawara islands in the north, northern Australia coast and Lord Howe Island in the south. The fish is considered reef-associated fishes and mainly feed on fishes and crustaceans [2, 3]. Despite its commercial importance, there is still deficient information on their biological characteristics, including length-weight relationships (LWR) and condition factors.

The LWRs information can be utilized to examine the growth shape between fish sexes [4-7], seasonal variation [4, 8, 9], the population from different locations $[5,9,10]$, and different environmental conditions [9]. On the other hand, the condition factor value can determine the state of a fish population in their habitat [11]. This information is essential in fisheries management.

There have been limited extensive studies on length-weight relationships (LWR) and condition factors of groupers in Aceh. For example, the study on the growth pattern of the leopard coralgrouper (Plectropomus leopardus), blacksaddled coralgrouper (P. laevis), duskytail grouper (E. bleekeri), and brownmarbled grouper (Epinephelus fuscoguttatus) [12]; the golden hind grouper (Cephalopholis aurantia) [13]; the orange-spotted grouper (Epinephelus coioides) [14] and white-edged lyretail (Variola albimarginata) [15]. However, similar information is not available for Cephalopholis argus in the northern Aceh region. Hence, the recent research's purpose was to expand further the biological investigations of $C$. argus harvested in the region.

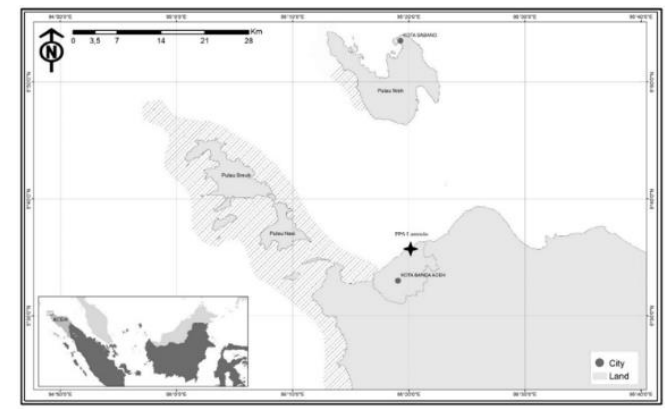

Fig. 1. Location of PPS Lampulo in the northern Aceh coast.

\footnotetext{
*Corresponding author: nurfadli@unsyiah.ac.id
} 


\section{Materials and Method}

The study was conducted from June - September 2020 in Pelabuhan Perikanan Samudera (PPS) Lampulo, Kuta Alam District, Banda Aceh, Aceh (Figure 1). For further analysis and measurements, the collected Cephalopholis argus samples were then transported to Genetics and Biodiversity Laboratory in the Faculty of Marine and Fisheries, Universitas Syiah Kuala.

The length-weight relationship (LWRs) was evaluated applying the linear allometric model (LAM) following De Robertis and Williams [16] and Muchlisin, Musman and Siti Azizah [17]. In addition, two condition factors were assessed in this study: Fulton's condition (K) [18] and Relative weight (Wr) [19].

Table 1. Values of several biological parameters, length, and weight relationships, and condition factors for Cephalopholis argus harvested on the northern coast of Aceh.

\begin{tabular}{lc}
\hline Parameters & mean $\pm \mathrm{SD}$ \\
\hline Total length $(\mathrm{mm})$ & $136.0-284.0(237.7 \pm$ \\
Body weight $(\mathrm{g})$ & $46.5-460.0(253.6 \pm 90.8)$ \\
Fulton's condition $(\mathrm{K})$ & $1.45-4.61(2.02 \pm 0.59)$ \\
Prediction weight $(\mathrm{Ws})$ & $41.77-419.52(251.50 \pm$ \\
(g) & $81.95)$ \\
Relative weight (Wr) & $81.75-128.53(100.59 \pm$ \\
(g) & $11.28)$ \\
$b$ Value & 3.1329 \\
\hline
\end{tabular}

\section{Results and Discussion}

Overall, 30 specimens of $C$. argus were compiled in this research. The observed total length (TL) of the fish samples varied from: 136.0-284.0 mm (mean $237.7 \pm$ 29.5) with weight (W): 46.5-460.0 g (mean 253.6 \pm 90.8). Additionally, the Fulton $(\mathrm{K})$ condition factor value ranged from 1.45 to 4.61 (mean $2.02 \pm 0.59$ ). The Ws values (predicted weight) ranged from 41.77 to $419.52 \mathrm{~g}$ (mean $251.50 \pm 81.95$ ). Furthermore, the relative weight $(\mathrm{Wr})$ for $C$. argus fish ranged from 81.75 to $128.53 \mathrm{~g}$ (mean $100.59 \pm 11.28$ ) (Table 1).

The linear allometric model (LAM) generated a $b$ value of 3.1329 with a correlation coefficient value of 0.94 . These results indicate that $C$. argus has a positive allometric growth pattern (Figure 2a). In addition, the regression model for the species showed a equal growth pattern between the observation and the prediction (Figure 2b).

The examined Fulton's condition factor $(\mathrm{K})$ was $>1$ $(2.02 \pm 0.59)$ and parallel with earlier grouper studies $[6$, $12,20]$. In addition, the average relative weight (Wr) was greater than $100(100.59 \pm 11.28 \mathrm{~g})$. The value corresponds with previous grouper studies worldwide $[13,14]$. Similar findings were also reported in several marine fishes surveys $[4,21]$. The $\mathrm{K}$ and $\mathrm{Wr}$ values observed in this study showed that the populations of $C$. argus harvested in this region are still in good condition.
Morton and Routledge [11] stated that a fish population is good when the $\mathrm{K}$ value is higher than 1 , while a $\mathrm{Wr}$ value is $>100$. Furthermore, the growth pattern of $C$. argus observed (positive allometry) in this study is similar to several other grouper species in northern Aceh $[12,13]$. This positive allometric growth pattern was also noted in many other marine fishes studies $[4,22]$.

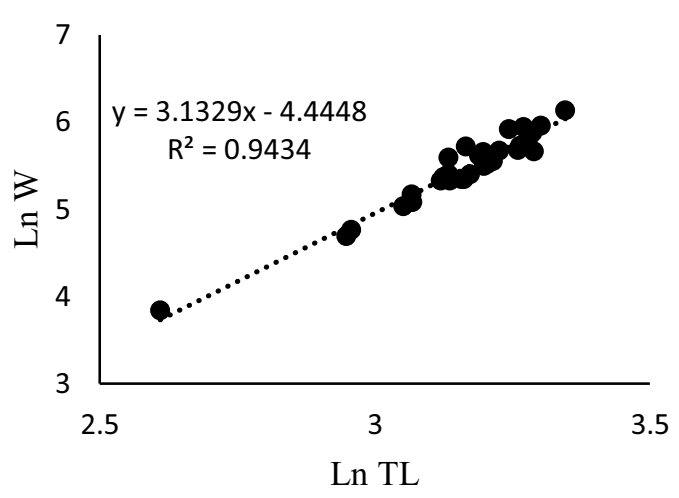

(a)

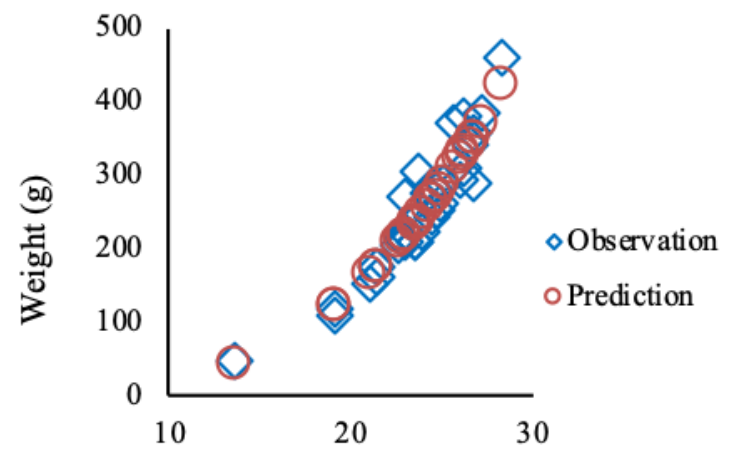

Total Length $(\mathrm{cm})$

(b)

Fig. 2. The length-weight relationships of $C$. argus (a) and comparison of observation and prediction growth (b).

Some abiotic factors were identified as the major factors affecting fish condition factors and growth patterns, such as environmental condition $[9,21]$ and temperature [23]. In addition to abiotic factors, biotic factors such as food accessibility [4] and predator density [21] also identified affected the fish condition factors and growth patterns.

This study provides length-weight relationships (LWR) and condition factors value for the peacock hind grouper that will assist in building a feasible fisheries management of the fish.

\section{Acknowledgments}

The study was funded by Universitas Syiah Kuala (Penelitian Calon Professor Research Scheme, contract number: 58/UN11.2.1/PT.01.03/PNBP/2021) and Universiti Malaysia Terengganu (Addressing Fisheries and Aquaculture Challenges in the Grouper (Family Epinephelidae) through Molecular Genetics with 
Special Focus on E. coioides UMT/RMIC/STRA/53280).

\section{References}

1. IUCN. The IUCN Red List of Threatened Species. Version 2019-1. ; 2019.

2. R. Froese,D. Pauly. (2019)

3. M.T. Craig, Y. Sadovy de Mitcheson,P.C. Heemstra. (2011)

4. D. Yulianto, I. Indra, A. Batubara, D. Efizon, F. Nur, S. Rizal, R. Elvyra,Z. Muchlisin. F1000Research 9, 259 (2020)

5. U.R. Zargar, A. Yousuf, B. Mushtaq,D. Jan. Turkish Journal of Fisheries and Aquatic Sciences 12, (2012)

6. U. Bulanin, M. Masrizal,Z.A. Muchlisin. Aceh Journal of Animal Science 2, 1 (2017)

7. M.S. Alavi-Yeganeh, S.J. Seyfabadi, Y. Keivany, B. Kazemi,G.P. Wallis. Journal of Applied Ichthyology 27, 6 (2011)

8. E.M. Kembenya, E.O. Ogello, C.M. Githukia, C.N. Aera, R. Omondi, J.M. Munguti. International Journal of Sciences: Basic and Applied Research 14, 2 (2014)

9. E.Ö. Özbek, T. Kebapçığlu,M. Çardak. Journal of the Black Sea/Mediterranean Environment 19, 1 (2013)

10. S. Munilkumar, Y. Rameshori, W.R. Mangang, M. Kamei, Y. Chinglemba, A. Pavan-Kumar, B.K. Mahapatra, A. Das, M.A. Hanif, M.A.B. Siddik. Journal of Applied Ichthyology 37, 2 (2021)

11. A. Morton,R.D. Routledge. North American Journal of Fisheries Management 26, 1 (2006)

12. A. Ramadhani, Z.A. Muchlisin, M.A. Sarong,A.S. Batubara. DEPIK Jurnal Ilmu-Ilmu Perairan, Pesisir dan Perikanan 6, 2 (2017)

13. N. Fadli, A. Damora, Z.A. Muchlisin, I. Dewiyanti, M. Ramadhaniaty, A. Hanif, C.S. Zahara, M. Rusdi, F.M. Nur, A.S. Batubara, M.N. Siti-Azizah. IOP Conference Series: Earth and Environmental Science 674, 1 (2021)

14. N. Fadli, A. Damora, Z.A. Muchlisin, I. Dewiyanti, M. Ramadhaniaty, Z. Zhelfi, N.F. Roka, F. Fitriani, M. Rusdi, F.M. Nur, A.S. Batubara,M.N. SitiAzizah. IOP Conference Series: Earth and Environmental Science 674, 1 (2021)

15. A. Damora, N. Fadli, Z.A. Muchlisin, I. Dewiyanti, A.S. Batubara, F.M. Nur, Z. Zhelfi, N.F. Roka, F. Fitriani,M.N. Siti-Azizah. IOP Conference Series: Earth and Environmental Science 674, 1 (2021)

16. A. De Robertis,K. Williams. Transactions of the American Fisheries Society 137, 3 (2008)

17. Z.A. Muchlisin, M. Musman,M.N. Siti Azizah. Journal of Applied Ichthyology 26, 6 (2010)

18. B.G. Blackwell, M.L. Brown,D.W. Willis. Reviews in Fisheries Science 8, 1 (2000)
19. A.L. Rypel, T.J. Richter. North American Journal of Fisheries Management 28, 6 (2008)

20. W. Ndiaye, K. Diouf, O. Samba, P. Ndiaye,J. Panfili. International Journal of Advanced Research 3, 3 (2015)

21. Z.A. Muchlisin, V. Fransiska, A.A. Muhammadar, M. Fauzi,A.S. Batubara. Croatian Journal of Fisheries 75, 3 (2017)

22. G. Mahadevan, S.M. Gosavi,P. Murugesan. Thalassas: An International Journal of Marine Sciences 36, 2 (2020)

23. W. Sabbir, M.Y. Hossain, M.A. Rahman, M.R. Hasan, Z. Mawa, S. Tanjin, H. Ul-Hassan,J. Ohtomi. Egyptian Journal of Aquatic Biology and Fisheries 24, 2 (2020) 